\title{
MENINGKATKAN DISIPLIN DAN TANGGUNG JAWAB PESERTA DIDIK DI ERA REVOLUSI INDUSTRI 4.0
}

\author{
Dewi Sartika, Sam Cay, Ading Sunarto, M.Anton Nurhidayat, \\ Raden Yeti Sumiaty \\ Universitas Pamulang \\ Email:dosen02208@unpam.ac.id
}

\begin{abstract}
At the PKM this time we took the object of research, namely students at the Rumah Yatim Lembaga Amil Zakat Nasional. Problems taken stem from the lack of knowledge and application of the discipline and responsibilities of students. The counseling program that will be provided by expert speakers is expected to be able to provide knowledge related to the above problems. The PKM program is expected to be an opportunity for students to discuss with speakers related to implementation and how to improve discipline and responsibility. The purpose of Community Service Activities is to carry out one of the Higher Education TriDharma. In addition, it is expected that through community service, the existence of higher education institutions can make a major contribution to the development and application of knowledge to the community. The method of activity used is that we go to the Rumah Yatim Lembaga Amil Zakat Nasional which is located at Jl. RE Martadinata No. 58 Pamulang, South Tangerang City and will provide training there on July 2-4, 2020. This training aims to make students at Rumah Yatim improve their discipline and responsibilities in the era of the industrial revolution 4.0 as it is today. The result of community service is the increase of knowledge for students at Rumah Yatim so that they have a good view of the importance of increasing discipline and responsibility at the present as their provision for life in the future. The knowledge gained at Community Service this time is expected to be able to provide new enthusiasm for us in delivering material and motivation as well as contributing to the young generation, both within the school, campus and family environments.
\end{abstract}

Keywords: Discipline, Responsibility, Industrial Revolution

\begin{abstract}
Abstrak
Pada PKM kali ini kami mengambil objek penelitian yakni peserta didik di Rumah Yatim Lembaga Amil Zakat Nasional. Masalah yang diambil berasal dari kurangnya pengetahuan dan penerapan disiplin dan tanggung jawab para peserta didik. Program penyuluhan yang akan diberikan oleh narasumber yang ahli diharapkan mampu memberikan pengetahuan terkait permasalahan diatas. Program PKM ini diharapkan menjadi kesempatan bagi para peserta didik berdiskusi dengan narasumber terkait implementasi dan cara meningkatkan disiplin dan tanggung jawab. Tujuan dari Kegiatan Pengabdian Kepada Masyarakat adalah untuk melaksanakan salah satu TriDharma Perguruan Tinggi. Selain itu diharapkan dengan pengabdian
\end{abstract}


kepada masyarakat tersebut keberadaan perguruan tinggi dapat memberikan kontribusi besar kepada pengembangan dan penerapan keilmuan kepada masyarakat. Metode kegiatan yang digunakan adalah kita mendatangi Rumah Yatim Lembaga Amil Zakat Nasional yang beralamat J1. RE Martadinata No. 58 Pamulang, Kota Tangerang Selatan dan akan memberikan pelatihan disana pada tanggal 02-04 Juli 2020. Pelatihan ini bertujuan agar siswa dan siswi yang ada di Rumah Yatim dapat meningkatkan disiplin dan tanggung jawab peserta didik di era revolusi industri 4.0 seperti sekarang ini. Hasil pengabdian masyarakat yang diperoleh adalah bertambahnya keilmuan bagi para peserta didik di Rumah Yatim agar mereka memiliki pandangan yang baik tentang pentingnya meningkatkan disiplin dan tanggung jawab pada masa kini sebagai bekal mereka untuk kehidupan di masa yang akan datang. Ilmu yang diperoleh pada Pengabdian Masyarakat kali ini diharapkan mampu memberikan semangat baru bagi kita dalam menyampaikan materi dan motivasi serta berkontribusi bagi generasi muda, baik dilingkungan sekolah, kampus dan keluarga.

Kata Kunci: Disiplin, Tanggung Jawab, Revolusi Industri

\section{A. PENDAhULUAN}

Pendidikan karakter memiliki peranan yang esensial dalam rangka mengatasi berbagai permasalahan bangsa Indonesia yang silih berganti muncul kepermukaan. Penguatan pendidikan karakter dalam konteks sekarang sangat relevan untuk mengatasi krisis moral yang sedang terjadi di negara Indonesia. Diakui atau tidak diakui saat ini terjadi krisis yang nyata dan mengkhawatirkan dalam masyarakat dengan melibatkan anak-anak. Sering terdengar berita di media massa bahwa anak-anak di bawah umur sudah melakukan kejahatan-kejahatan yang di luar dugaan, hal ini disebabkan karena karakter yang lemah dari anak tersebut. Oleh sebab itu, maka penguatan pendidikan karakter sangat relevan untuk mengatasi berbagai permasalahan di bangsa ini. Disiplin merupakan tindakan yang menunjukkan perilaku tertib dan patuh pada berbagai ketentuan dan peraturan. Adapun dari indikator disiplin tersebut yaitu membiasakan hadir tepat waktu, membiasakan mematuhi aturan, menggunakan pakaian sesuai jadwal. Begitu juga dengan tanggung jawab yang merupakan sikap dan perilaku seseorang untuk melaksanakan tugas dan kewajibannya yang seharusnya dia lakukan. Indikator dari tanggung jawab antara lain melaksanakan tugas piket secara teratur, peran serta aktif dalam kegiatan sekolah, mengajukan usul pemecahan masalah. Namun, dalam era global sekarang ini banyak siswa dan bahkan hampir semua siswa di sekolah tidak memiliki sifat karakter disiplin dan tanggung pada diri mereka. Hal ini menunjukan bahwa sulitnya menerapkan 3 pendidikan karakter di sekolah. Krisis karakter ini sudah terjadi sejak lama menjadi masalah dalam pendidikan dan sulit untuk mendapatkan solusinya.

Kenyataan terjadi pada saat ini dilapangan, anak selalu kurang disiplin dan kurang memiliki rasa tanggung jawab di sekolah, tidak membuat pekerjaan rumah, mencoret coret bangku, tidak biasa antre, pada saat upacara bendera tidak tertib, tidak berpakaian dengan rapi, sering datang terlambat, menyerahkan tugas tidak tepat waktu, di dalam kelas selalu mengganggu teman, sering berkelahi, serta kurang hormat pada guru. Hal tersebut ini merupakan dasar dalam pembentukan watak dan kepribadian siswa. Jikalau kebiasan ini tidak menemukan pemecahan masalahnya maka tujuan pendidikan nasional akan 
sulit terwujud. Berbagai faktor yang mempengaruhi anak kurang menunjukkan sikap tersebut, diantaranya lemahnya perhatian orang tua kepada anaknya dikarenakan orang tua selalu sibuk dengan urusan ekonomi, orang tua yang otoriter, keluarga yang broken home, pengaruh pergaulan di lingkungan sekitar anak, adanya perkembangan media elektronik, kurang demokratisnya pendekatan dari orang tua maupun guru yang ada di sekolah. Dengan memberikan sanksi berjenjang di sekolah pada siswa diharapkan dapat merubah sikap dari kurang disiplin dan kurang bertanggung jawab menjadi anak yang berdisiplin dan bertanggung jawab. Di era industri 4.0 perkembangan teknologi sangat masif dan cepat sampai tidak bisa diprediksi dampaknya. Dampak yang diakibatkan di era industri 4.0 berpengaruh terhadap dunia kerja dan pendidikan. Selain itu, dampak teknologi digital ini juga ikut mewarnai pada aspek pola kerja, waktu kerja, cara kerja, dan segala aspek jenis pekerjaan akan berubah sebagai akibat dari adanya revolusi industri 4.0. Demikian pula pada dunia pendidikan, niscaya berubah bergerak maju sebagai akibat dari dampak revolusi industri 4.0. Maka pendidikan tidak bisa tinggal diam begitu saja dalam menyikapi bentuk perubahan yang begitu cepat dan mengglobal. Pendidikan mesti terlibat dalam arus globalisasi dengan melakukan inovasiinovasi. Hal ini, bertujuan untuk memberikan metode dan strategi baru yang relevan terhadap peserta didik dalam proses pembelajaran di dalam kelas. Sedangkan dalam sistem pembelajarannya, seorang guru harus bisa memahami kebutuhan peserta didik, tidak hanya membekali dengan kekayaan teknologi, melainkan juga membekali dalam hal spritualitas. Mengingat nilai-nilai etika, kebijaksaan, dan budi pekerti tidak dapat diajarkan oleh mesin. Oleh karena itu, nilai-nilai spiritualitas sangat penting untuk membentengi peserta didik dari dampak teknologi yang begitu masif perkembangannya. Dengan demikian, peran guru di lembaga sekolah sangat urgent untuk memberikan materi yang tepat terhadap peserta didik. Agar peserta didik tidak hanya memiliki kecakapan dalam bidang ilmu teknologi, tetapi juga memiliki nilai-nilai karakter yang berlandaskan pada etika, moral, dan akhlak. Karena pembentukan karakter merupakan salah satu tujuan yang ingin dicapai dalam pelaksanaan pendidikan nasional. Dalam konteks ini, agar pembentukan karakter peserta didik dapat terealisasi sesuai dengan tujuan awal pendidikan nasional yang berorientasi pada nilai-nilai luhur bangsa dan negara. Maka dibutuhkan penguatan dan pengembangan nilai-nilai kehidupan terhadap peserta didik.

Dengan mempertimbangkan latar belakang yang telah dijelaskan diatas kami berinisiatif untuk membentuk pengabdian masyarakat bagi peserta didik yang ada di Rumah Yatim Lembaga Amil Zakat Nasional khususnya dalam program pelatihan agar dapat meningkatkan disiplin dan tanggung jawab di era revolusi industri 4.0 ini.

\section{B. METODE PELAKSANAAN KEGIATAN}

Metode kegiatan yang digunakan adalah dengan melakukan kunjungan langsung ke Rumah Yatim Lembaga Amil Zakat Nasional yang beralamat di Jl. RE Martadinata No. 58, Pamulang, Kota Tangerang Selatan dan akan memberikan pelatihan disana pada tanggal 02-04 Juli 2020.Kegiatan pengabdian kepada masyarakat dilakukan dengan metode sebagai berikut:

1. Identifikasi masalah yang dilakukan sebagai langkah awal untuk merumuskan apa saja yang akan dijadikan bahan untuk perancangan sistem dan materi pelatihan dalam kegiatan pengabdian ini.

2. Melakukan survei lapangan ke Rumah Yatim Lembaga Amil Zakat Nasional sebagai tempat dilaksanakannya kegiatan. Kemudian melakukan proses wawancara dan diskusi dengan pihak rumah yatim untuk identifikasi permasalahan yang ada dalam lingkungan peserta didik. 
3. Kontribusi pengusul dalam proses pengabdian dengan melakukan penelitian pustaka untuk acuan materi yang digunakan selama kegiatan pengabdian.

Pelatihan ini bertujuan agar peserta didik yang ada di Rumah Yatim Lembaga Amil Zakat Nasional dapat meningkatkan rasa disiplin dan tanggung jawabnya dalam kehidupan sehari-hari.

\section{HASIL DAN PEMBAHASAN}

\section{Tahap Persiapan}

Sebelum melaksanakan Pengabdian Kepada Masyarakat kami selaku Dosen Universitas Pamulang melakukan pra-survey ke tempat yang akan menjadi tujuan PKM kami yakni di Rumah Yatim Lembaga Amil Zakat Nasional. Pelatihan ini bertujuan agar para peserta didik yang ada di Rumah Yatim dapat meningkatkan disiplin dan tanggung jawab di era revolusi industri 4.0 seperti sekarang ini.

Setelah itu, TIM PKM yang terdiri dari lima orang Dosen UNPAM melakukan Forum Group Discussion (FGD) untuk mempersiapkan pelaksanaan Pengabdian Kepada Masyarakat (PKM) untuk tanggal 02-04 Juli 2020.

\section{Tahap Pelaksanaan Pengabdian Kepada Masyarakat}

Pelaksanaan Pengabdian Kepada Masyarakat di Rumah Yatim dilaksanakan pada tanggal 02-04 Juli 2020. Kegiatan dilaksanakan di Rumah Yartim yang beralamat di Jl. RE Martadinata No. 58 Pamulang Tangerang Selatan. Kegiatan ini terlaksana atas kerjasama Universitas Pamulang dengan Rumah Yatim, pelatihan ini bertema "Meningkatkan Disiplin dan Tanggung Jawab Peserta Didik di Era Revolusi Industri 4.0”.

\section{Tahap Pelatihan}

Untuk melaksanakan kegiatan tersebut digunakan beberapa metode pelatihan yaitu:

a. Metode ceramah

Metode yang digunakan dalam pelatihan SDM dimulai dengan memberikan ceramah atau presentasi dengan tema "Meningkatkan Disiplin dan Tanggung Jawab Peserta Didik di Era Revolusi Industri 4.0"

b. Metode tanya jawab

Setelah sesi ceramah sudah selesai, maka dilanjutkan dengan sesi tanya jawab. Hasilnya, peserta sangat antusias untuk menanyakan bagaimana cara meningkatkan disiplin dan tanggung jawab serta implementasinya pada kehidupan sehari-hari. Peserta yang bertanya kami berikan cendremata dari Universitas Pamulang dan sumbangsih dari dosen-dosen UNPAM.

c. Metode simulasi

Pelatihan ini juga diberikan metode simulasi, sehingga peserta langsung dapat mempraktekan apa yang sudah disampaikan. Apabila ada kendala maka langsung dibantu pada saat pelaksanaan PKM. Simulasi penting dilakukan untuk mengetahui seberapa besar tingkat pengetahuan dan ilmu yang diserap pada saat pelatihan.

\section{KESIMPULAN DAN SARAN}

\section{Kesimpulan}

Pelaksanaan kegiatan Pengabdian Kepada Masyarakat oleh Lembaga Penelitian dan Pengabdian Masyarakat (LPPM) Universitas Pamulang yang dilakukan oleh dosen-dosen program studi Manajemen telah berjalan dengan lancar dan mendapat sambutan hangat dari tempat pelaksanaan kegiatan ini Rumah Yatim Lembaga Amil Zakat Nasional. Harapan kami 
dengan pengabdian ini dapat menambah ilmu yang bermanfaat dalam hal sikap disiplin dan tanggung jawab.

Dalam laporan kegiatan ini mungkin banyak kekurangan yang ada, untuk itu kami berharap masukan dan kritikan dalam rangka perbaikan untuk kegiatan-kegiatan pengabdian masyarakat di masa yang akan datang. Semoga kegiatan pengabdian masyarakat ini dapat bermanfaat bagi masyarakat sekitar lingkungan Universitas Pamulang dan lainnya.

Akhirnya, kami mengucapkan terima kasih kepada seluruh pihak yang telah mendukung kegiatan yang kami laksanakan dan kami mohon maaf apabila dalam laporan ini banyak ditemukan kekurangan.

\section{Saran}

Berdasarkan hasil kegiatan Pengabdian Kepada Masyarakat, maka kami dari Tim Dosen Universitas Pamulang memberikan saran diantaranya sebagai berikut:

1. Untuk pihak pengelola Rumah Yatim dan jajaran agar lebih menekankan sikap disiplin dan tanggung jawab peserta didik yang berada di sana agar hal tersebut dapat menjadi bekal sukses mereka kelak di kemudian hari.

2. Adanya kontribusi dari pihak universitas untuk bisa memberikan fasilitas dalam pelayanan kepada masyarakat dalam bentuk sarana dan prasarana.

\section{Ucapan Terima Kasih}

Rasa syukur dan suka cita kami haturkan kepada segenap pihak yang telah menyukseskan kegiatan PKM dengan judul "Meningkatkan Disiplin dan Tanggung Jawab Peserta Didik di Era Revolusi Industri 4.0 di Rumah Yatim Lembaga Amil Zakat Nasional" kepada:

1. Rektor Dr. H. Dayat Hidayat, M.M, Rektor Universitas Pamulang Tangerang Selatan Banten.

2. Dr. Ali Maddinsyah, S.E., M.M., selaku Ketua LPPM Universitas Pamulang Tangerang Selatan - Banten.

3. Dr. Kasmad, S.E., M.M., selaku Ketua Program Studi Manajemen Universitas Pamulang Tangerang Selatan - Banten.

4. Dr. Udin Ahidin, S.E., M.M., C.M.A, Selaku Wakil Program Studi Manajemen Universitas Pamulang Tangerang Selatan - Banten.

5. Drs. Waluyo Jati, M.M., Selaku Sekretaris Program Studi Manajemen Universitas Pamulang Tangerang Selatan - Banten.

6. Bapak Sani Ramdani selaku Pimpinan Rumah Yatim Lembaga Amil Zakat Nasional Pamulang Kota Tangerang Selatan - Banten.

7. Mahasiswa Universitas Pamulang yang juga ikut berkontribusi terhadap kelancaran kegiatan PKM.

\section{DAFTAR PUSTAKA}

Ainia, Q., Kurniasih, N., \& Sapti, M. (2012). Eksperimentasi Model pembelajaran Auditory Intellectually Repitition (AIR) terhadap Prestasi Belajar Matematika Ditinjau dari Karakter Belajar Siswa Kelas VII SMP Negeri Se-Kecamatan Kaligesing Tahun 2011/2012. Prosiding, 709-716.

Codrington, Graeme \& Sue Grant-Marshall. (2004). Generation Theory, Penguin.

Hussin, A. A. (2018). Education 4.9 Made Simple: Ideas For Teaching. International Journal of Education \& Literacy S tudies, 6(3), 92-98. 
Maria, M., Shahbodin, F., \& Pee, N. C. (2016). Malaysian higher education system toward industry 4.0 - Current trends overview. Proceeding of the $3 \mathrm{rd}$ International Conference on Applied Science and Technology (AIP Publishing), 1-7.

Siregar, Ucok Setia. (2017). Meningkatkan Disiplin dan Tanggung Jawab Siswa Melalui Sanksi Berjenjang Pada Siswa Kelas V .Manajer Pendidikan, Volume 10, Nomor1,Maret 2017, hlm.109-114. ISSN: 1979-732X

Sugiyono. (2014). Metode Penelitian Pendidikan Pendekatan Kuantitatif, Kualitatif, dan $R$ dan D. Bandung: Alfabeta

Sukaraman, Heri. (2003). Dasar-Dasar Didaktik dan Penerapannya dalam Pembelajaran. Jakarta: Depdiknas Dirjen Pendasmen, Direktorat Tenaga Kependidikan

Undang-Undang SISDIKNAS (Sistem Pendidikan Nasional) No. 20 Th. 2003. 2008. Jakarta: Sinar Grafika.

Wibawa, S. (2018). Pendidikan dalam Era Revolusi Industri 4.0. Indonesia "7 Provinsi Raih Nilai Terbaik Uji Kompetensi Guru 2015”, https://www.kemdikbud.go.id/ diakses pada 1 Mei 2019

Wijaya dan Rusyan. (1994). Kemampuan Dasar Guru dalam Proses Belajar Mengajar.Bandung: Remaja Ris Dakarya 